\title{
РОЗВИТОК ПОЗАШКІЛЬНОЇ ОСВІТИ УКРАЇНИ У ПЕРШІЙ ПОЛОВИНІ ХХ СТОЛІТТЯ
}

\author{
Костенко Л. Д. \\ кандидат педагогічних наук, \\ начальник Управління освіти \\ Міська рада міста Кропивницького \\ вул. Велика Перспективна, 41, Кропивницький, Україна \\ orcid.org/0000-0003-2930-7404 \\ t.vladimirovna.75@ukr.net
}

\author{
Ключові слова: позашкільна \\ освіта, дозвілля, позашкільне \\ виховання, позашкільний \\ заклад, діти та підлітки, \\ форми та методи \\ позашкільної освіти.
}

У статті здійснено аналіз розвитку теоретичних основ і практики позашкільної освіти, який дав можливість автору зробити узагальнення, що вона має свою історію, зумовлену багатогранністю змісту і форм здійснення. Автор констатує, що роком народження позашкільної освіти в Україні як унікальної освітньої ланки вважається 1918 р. В уряді молодої української держави саме цього року громадський діяч, видатний педагог С. Русова очолила два відділи - шкільного виховання та позашкільної роботи. До 1917 р. простежувалися лише певні елементи цієї роботи. Термін «позашкільна освіта» в сучасному значенні увійшов у понятійний апарат у кінці XIX ст.

У дослідженні наголошується, що початок XX ст. характеризується бурхливими політичними і соціальними змінами. Розвиток демократії, зростання національного руху в країні сприяли активізації роботи 3 дітьми та підлітками, що стало об'єктивною необхідністю виховання нової особистості і зумовило розширення мережі освітніх закладів у сфері дозвілля: функціонували недільні школи, різноманітні гуртки й курси, Народні будинки, які здійснювали культурно-освітню роботу, організовували лекції, вистави, екскурсії, створювали драматичні й хорові колективи, бібліотеки-читальні тощо. Було створено перші клуби для дітей і підлітків із бідних сімей з метою організації їхнього дозвілля, урахування інтересів до театру, музики, науки, образотворчого мистецтва тощо.

У статті виокремлюються особливості позашкільної освіти на початку XX ст.: розширення іï змісту та урізноманітнення форм організації в позашкільних та інших навчальних закладах. Йшов пошук шляхів розвитку освіти дітей поза школою. Велася аналітична робота, приходило усвідомлення необхідності створення умов для позашкілля. Цей час розглядається як підготовчий у створенні системи позашкільної освіти. Характерним для 20-30-х рр. ХХ ст. автор називає зв'язок виховання 3 виробництвом, який давав дітям можливість, ознайомившись із декількома професіями, обрати ту чи іншу з них відповідно до власних здібностей i бажань, що сприяло їхній соціалізації в суспільстві. У публікації обгрунтовано, що в 1930-1940рр. система позашкільної освіти набувала подальшого розвитку. Мережа позашкільних закладів, зміст позашкільного виховання орієнтувалися на зв'язок із життям, вирішення завдання всебічного розвитку особистості, підготовку до праці та продовження навчання. 


\title{
THE DEVELOPMENT OF OUT-OF-SCHOOL EDUCATION OF UKRAINE IN THE FIRST HALF OF THE XX CENTURY
}

\author{
Kostenko L. D. \\ Candidate of Pedagogical Sciences, \\ Head of the Education Department \\ Kropyvnytskyi Town's Council \\ Velyka Perspektyvna str., 41, Kropyvnytskyi, Ukraine \\ orcid.org/0000-0003-2930-7404 \\ t.vladimirovna.75@ukr.net
}

\begin{abstract}
Key words: out-of-school education, leisure, out-of-school up-bringing, out-of-school institution, children and teenagers, forms and methods of out-of-school education.
\end{abstract}

\begin{abstract}
The article analyzes the development of theoretical foundations and practice of out-of-scool education, which allowed the author to make a generalization that it has its own history, due to the diversity of content and forms of implementation. The author states that 1918 is considered to be the year of the birth of out-of-school education in Ukraine as a unique educational unit. That very year an outstanding educator and public figure S. Rusova became the head of two departments: school education and out-of-school education in the government of the young Ukrainian state. Before 1917, only certain elements of this activity could be traced. The term "out-of-school education" in its modern sense entered the conceptual apparatus in the end of the nineteenth century. The research notes that the beginning of the twentieth century is characterized by rapid political and social changes. The development of democracy, the growth of the national movement in the country promoted the intensification of work with children and teenagers, which became an objective necessity for up-bringing of a new personality and led to the extension of the network of educational institutions in the field of leisure-there appeared Sunday schools, different societies and courses, Narodny budinky, which realized cultural- educational activities, organized lectures, performances, excursions, created drama societies and choir groups, libraries and reading rooms, etc. The first clubs for children and teenagers from poor families were established in order to organize their leisure, considering their interests in theatre, music, science, fine arts, etc.

The article distinguishes peculiar features of out-of-school education at the beginning of the twentieth century: the extension of its content and the diversification of forms of organization in out-of-school and other educational institutions. There was a search for ways to develop out-of-school education for children. Analytical work was carried out and finally they came to realize the necessity to create conditions for out-of-school activities. This time is seen as preparatory to the creation of an out-of-school educational system. The author notes that the connection between upbringing and production was a characteristic feature in the 20's and 30's of the twentieth century. On getting acquainted with some professions the children had an opportunity to choose one of them according to their own inclinations and desires, which contributed to their socialization in the society. The article proves that in 1930-1940 the system of out-of-school education got further development. The network of out-of-school institutions, the content of out-of-school education focused on its connection with life, solving the task of an all-round development of a personality, preparation for its work and continuation of studying.
\end{abstract}

Постановка проблеми. В умовах сьогодення позашкільна освіта стає все більш актуальною та пов'язаною з необхідністю розбудови української школи відповідно до сучасних вимог. Позашкільна освіта надає можливість учням розкрити свої здібності, таланти, працювати творчо, активно, самостійно. У позашкільних закладах діти долучаються до інтелектуальної, творчої, трудової, естетичної, спортивної та інших видів діяльності, яка вимагає розроблення наукового, грунтовного, історично вивіреного організаційно-педагогічного забезпечення їхнього функціонування. 
Вирішенню цих завдань, безумовно, сприяє як упровадження нових освітніх технологій, так i звернення до історичної педагогічної традиції позашкільних закладів.

Окремі питання сучасних методологічних засад позашкільної освіти та виховання, позашкільної роботи наведені у працях українських учених: І. Беха, В. Борисова, А. Капської, В. Мадзігона, Г. Пустовіта, О. Сухомлинської, Т. Сущенко та інших.

Історичні основи становлення $\mathrm{i}$ розвитку позашкільних навчальних закладів розкрито в роботах В. Береки, О. Глух, А. Сиротенка, Т. Цвірової, А. Шепілової та інших.

Мета статті - на основі історико-педагогічного аналізу розкрити розвиток теорії та практики позашкільної освіти України у першій половині XX ст., охарактеризувати її зміст і форми.

Виклад основного матеріалу дослідження. Розвиток позашкільної освіти як в Україні, так і поза іiі межами зумовлений певними конкретноісторичними умовами (соціальними, економічними, політичними), що визначають іїі найважливішу закономірність.

Роком народження позашкільної освіти в Україні як унікальної освітньої ланки вважається 1918 р. В уряді молодої української держави саме цього року громадський діяч, видатний педагог С. Русова очолила два відділи - шкільного виховання та позашкільної роботи. До 1917 р. простежувалися лише певні елементи цієї роботи. Термін «позашкільна освіта» в сучасному значенні увійшов у понятійний апарат у кінці XIX ст.

Початок XX ст. характеризується бурхливими політичними i соціальними змінами. Розвиток демократії, зростання національного руху в країні сприяли активізації роботи з дітьми та підлітками, що стало об'єктивною необхідністю виховання нової особистості і зумовило розширення мережі освітніх закладів у сфері дозвілля.

На початку XX ст. в Ніжині, Києві, Харкові були організовані i перші будинки юнацтва. Широко відомими стали клуби хлопчиків-прикажчиків, шевців, кравців. Одночасно із клубами i будинками соціального виховання для бідняків, ремісників і міщан створювалися будинки для гімназистів, кадетів, учнів реальних училищ, дітей і молоді, батьки яких належали до «вищого світу». За ознакою соціального походження і типом трудової діяльності було створено такі клуби і для дівчат, але їх було значно менше. До початку Першої світової війни клуби починають функціонувати в усіх містах, у тому числі і в сільській місцевості [1].

Потужного поштовху розвитку різних форм позашкільної освіти надали революційні події 1905-1907 pp. Нові починання у цій сфері на початку XX ст. пов'язані з іменами В. Вентцеля, А. Зеленка, С. Шацького та інших. Значний інтерес в узагальненні практики позашкільної освіти становить педагогічний досвід А. Зеленка, С. Шацького, К. Фортунатова. 31905 р. вони створювали дитячі клуби-гуртки та дитячі садки під загальною назвою «Денний притулок для прихожих дітей» [2].

У 1905 р. були створені гуртки та клуби агрономічного, сільськогосподарського, біологічного й натуралістичного профілів у містах Ніжині, Харкові, Києві. 31909 р. в українських гімназіях почала діяти «Самовиховна шкільна громада», котра організовувала для учнів прогулянки та екскурсії у природу, історичні екскурсії [2]. У цей час стають популярними виробничі екскурсії на заводи, шахти, рудники, телефонні станції, типографії тощо. У 1911 році створюється одна з найстаріших наукових установ України - Носівська селекційно-дослідна станція [2].

Суттєві зміни в організації позашкільного життя дітей та учнівської молоді відбулися в Україні після революційних подій 1917 р. Для реалізації завдань навчання та виховання дітей створювалися перші центри позашкільної освіти. Особливим попитом в Україні в 1918-1919 рр. користувалися невеликі дитячі клуби, комуни, секції, у яких навчально-виховним процесом керували комсомольці. Вони працювали в гуртках, створювали бібліотеки, майстерні. Дитячі об'єднання і клуби ставили собі за мету залучення дітей до активної участі в будівництві нового життя. Такі організації були прообразом сучасних позашкільних закладів освіти, першою базою дитячих політичних організацій. 31917 по 1920 р. в Україні було створено Департамент позашкільної освіти, який сприяв створенню закладів нового типу.

3 відродженням у 1917 р. української державності, із проголошенням Українською Центральною Радою Української Народної Республіки уряди УНР (1917-1920) і Гетьманської Української держави (1918) у складних історичних умовах усвідомлювали важливість освіти як чинника державотворення і як засобу впливу на настрої та переконання народних мас, формування політично, світоглядно свідомої соціальної бази української влади [3]. Відкривалися бібліотеки, клуби тощо.

У міру утвердження радянської влади дія законодавчих актів більшовицького уряду Росії поширюється і на Україну. Першими важливими нормативними актами російської радянської влади стосовно освіти були «Положення про єдину трудову школу РСФРР» та «Декларація про єдину трудову школу» (1918). Значна увага в цих документах надавалася фізичному розвитку та естетичному вихованню дітей, а також повазі до особистості дитини та розвитку ії творчих сил. 
У формуванні радянської теорії і практики позашкільної освіти виняткова роль належала державному і партійному діячу, теоретику і організатору народної освіти Н. Крупській [1]. Основна робота 3 народної просвіти покладалася на новостворені ради народної просвіти та робітничі культурно-просвітницькі організації. У містах та селах відкривались школи, створювалися бібліотеки, розпочинали роботу народні будинки, дитячі садки та майданчики, клуби, театри.

У 1919 р. при Наркомосвіти був створений спеціальний підвідділ шкільних трудових колоній та дитячих клубів, в обов'язки якого входила організація дитячих трудових колоній, клубів, майданчиків, бібліотек-читалень для школярів та дітей шкільного віку [2]. Основний зміст позашкільної освіти був спрямований на соціалізацію дітей в умовах різких змін у політичному, соціальному, культурному житті країни, на залучення їх до суспільного життя.

Серед форм позашкільної роботи поширеними у 1918-1919 рр. були дитячі майданчики, трудові колонії, масові заходи. Так, дитячі майданчики створювалися за ініціативою місцевих органів народної просвіти та культкомісій ревкомів, Червоної Армії, залізничних організацій, жіночих рад. Функціонування майданчика передбачалося впродовж трьох літніх місяців для дітей від 3-4 до 15 років. У переліку форм роботи були гімнастика, екскурсії, прогулянки, співи, розповіді. Важливою була організація діяльності дітей на трудових засадах та самообслуговування.

Не менш важливою формою позашкільної роботи цього періоду були літні трудові колонії. Це зумовлено тим, що організаційно-педагогічною і соціально-педагогічною проблемою був літній відпочинок дітей, організація їхнього дозвілля і трудового виховання [4]. Поряд із практичними видами діяльності реалізовувалися розважальні програми, ігри.

Важливою формою позашкільної роботи у 1918-1919 рр. стали дитячі масові заходи. За розпорядженням органів нової влади ревкоми та просвітницькі товариства організовували дитячі свята, ранки, мітинги, гуляння, вистави, концерти, кінопокази. Для того щоб залучити якомога більше дітей у коло організованого, ідейно спрямованого дозвілля, ці заходи проводилися не тільки в школах, але й у клубах, театрах або просто у дворах будинків. Спочатку зміст дитячих свят мав в основному розважальний характер. Влаштовувалися веселі концерти, роздавалися подарунки, організовувалися різноманітні ігри. Згодом представники радянської влади стали використовувати такі заходи передусім для ідейного впливу на дітей та молодь.

Упродовж 1920-1930 рр. складалася певна система позашкільного виховання, визначилися iii завдання, що полягали в посиленні освітньої роботи як допомоги школі, а також в організації дозвілля [5]. Це зумовлено прийняттям низки офіційних документів, які визначили шляхи розвитку позашкільної освіти, виховної роботи 3 дітьми і підлітками. Серед них - «Декларація Наркомосвіти УРСР про соціальне виховання дітей» (1920), постанова «Про дитячі будинки» (1920). У 1920-1925 рр. у державі створювалися передусім заклади (установи) соціального виховання (денні дитячі будинки, відкриті дитячі будинки, притулки, дитячі майданчики, літні колонії, школи-клуби), головними функціями яких були боротьба з безпритульністю, бездоглядністю, врятування та соціальний захист дітей і підлітків [5].

У 20-30-х pp. ХХ ст. в Україні починають створюватися нові типи позашкільних закладів, започатковуються нові форми виховання, які сприяють соціалізації дітей та підлітків: дитячі театри, дитячі екскурсійні бюро та екскурсійні станції, агробіостанція, дитяча технічна та сільськогосподарська станція, республіканська екскурсійно-туристична станція, дитяча водна станція, агробаза [6]. Починають друкуватися перші дитячі газети та журнали; з'являється перша радіопередача для дітей.

Незважаючи на надмірну політичну спрямованість виховної роботи 3 дітьми, можемо констатувати значні досягнення у вирішенні проблеми соціалізації дітей в умовах позашкільного закладу. Зазначимо, що масштабні зміни у системі освіти відбувалися в надзвичайно складних політичних умовах, під час голоду й розрухи. За даними станом на 1921 р., в Україні майже 95\% дітей шкільного віку не мали можливості відвідувати школу, а кількість безпритульних дітей перевищувала 1,5 млн осіб. У цих умовах відновлення прототипів сучасних позашкільних закладів починає набувати незаперечного значення. Вирішуючи ці проблеми, радянський уряд приділяє особливу увагу посиленню виховної роботи та створенню i зміцненню матеріальної бази позашкільних закладів. 3 цією метою у 1922 р. постановою ЦК КП(б) У за позашкільними закладами були закріплені як шефи промислові підприємства.

Визначну роль у подальшому розвитку системи позашкільного виховання дітей у 1920-х рр. відіграло створення комсомольської і піонерської організацій, що ще більше посилило ідейно-політичну спрямованість роботи позашкільних закладів, яка нерідко набувала виявів цілковитої заідеологізованості. Водночас розвивалася мережа дитячих клубів.

Розвиток клубного руху в літній період сприяв появі нових форм позашкільної роботи, які поклали початок організації нових типів дитячих позашкільних закладів, таких як дитячі спортивні майданчики, піонерські табори, оздоровчі колонії, водні станції. 
В умовах дитячої безпритульності поширення позашкільної виховної роботи з дітьми мало особливе значення. Саме у цей час розмаху набуває діяльність А.С. Макаренка, який успішно керував колонією імені М. Горького, згодом у передмісті Харкова - комуною імені Ф.Е. Дзержинського.

Створення в 1922 р. Союзу Радянських Соціалістичних Республік зумовило перехід до нового розуміння цілей і завдань системи освіти, зокрема позашкільної. Було визначено, що позашкільна освіта потрібна для культурного поступу країни як найкращий засіб виховання гармонійно розвиненої особистості, нових «будівників» комунізму.

Значним поширенням гурткової роботи 3 дітьми, яка проводилася за участю широких кіл громадськості і під обов'язковим керівництвом партійних і комсомольських органів, характеризуються 1926-1927 рр. Так, на Київському заводі «Більшовик» для юних техніків був заснований радіогурток, на заводі «Ремповітря» - електрогурток, на Харківському паровозобудівному заводі для учнів були засновані столярна та швейна майстерні [6]. Їх роботою керували робітники та інженери підприємств.

Незважаючи на певні успіхи, якими система позашкільного навчання характеризувалася загалом, були численні недоліки. Так, у роботі з дітьми переважно практикувалися форми та методи, притаманні роботі з дорослими. Звідси - надмірна «політизація» піонерської роботи, зниження рівня культурно-просвітницької діяльності, прорахунки в організації дозвілля.

У 1930-1940 рр. відбувався перехід до планового розвитку мережі позашкільних закладів, пошук нових, більш дієвих форм організації підростаючого покоління; здійснювався процес удосконалення всіх ланок системи позашкільного виховання, які забезпечували реалізацію завдань політехнічного, трудового, технічного, естетичного і морального розвитку дітей і підлітків [1]. Водночас утвердилися основні принципи взаємодії позашкільного і шкільного виховання.

3 початку 1930-х рр. позашкільна робота стала розглядатися як частина загального процесу комуністичного виховання. Позашкільна освіта була замінена позашкільним вихованням, що спричинило зміни деяких функцій позашкільних закладів, особливо будинків піонерів. Відповідно до прийнятого плану розвитку мережі позашкільних закладів на другу п'ятирічку в усій країні відбулося масове відкриття закладів різних типів [6]. Насамперед відкривалися перші комплексні позашкільні заклади - палаци та будинки піонерів і жовтенят. Функціонували такі типи позашкільних закладів, як: дитяча кімната при житлокооперативах (початкова ланка, найбільш простий тип дитячого закладу, який забезпечував культурне дозвілля дитини); дитячий клуб; дитячі технічні станції; екскурсійно-туристські станції; дитячі стадіони, фізкультурні та оздоровчі майданчики, водні станції та басейни, лижні станції та дитячі парки; театри юного глядача, театри ляльок, музичні школи, кінотеатри; дитячі бібліотеки; палац культури - комплекс, до якого входять дитячі клуби, драмтеатр, бібліотека, робочі кімнати, лабораторії дитячої праці, станції дозвілля, екскурсійна база; дім комдитруху. Зароджувався рух червоних слідопитів, тимурівців, проводилися спеціальні дитячі воєнізовані походи, оборонно-спортивні ігри. У численних оборонно-спортивних гуртках учні починають вивчати військові спеціальності.

В 30-х pp. ХХ ст. в Україні масово створюються заклади позашкільної освіти нового типу - палаци піонерів та жовтенят, аналогів яких не було в жодній країні світу. Це були комплексні заклади, в яких організовувалося цікаве дозвілля, розумний відпочинок, саме тут виявлялися здібності та таланти, задовольнялися дитячі запити. Новостворені палаци залучали до своїх гуртків, секцій величезну кількість учнів, а також ставали головними методичними центрами позашкільної роботи. Зокрема, у Київському палаці дітей та юнацтва, який був створений 13 жовтня 1934 р., відразу запрацювала шахова школа, розпочалися заняття в музичній, хореографічній, а згодом і у вокальній школах, створено клуб юних туристів, лабораторії, фізкультурний зал, зимовий сад, бібліотека. Створення відповідних закладів започатковується майже у всіх обласних центрах [2].

До початку Великої Вітчизняної війни в Україні була створена і функціонувала широка мережа позашкільних закладів різних типів. Найважливішими принципами позашкільної роботи були ідейна спрямованість, зв'язок із суспільним життям, розвиток ініціативи і творчості вихованців, забезпечення можливості участі кожного учня в різних видах діяльності відповідно до його інтересів і віку. Позашкільне виховання й навчання дітей і підлітків спрямовувалося на задоволення їхніх культурних інтересів і запитів, розвиток самодіяльності та творчих здібностей, організацію розумного та цікавого дозвілля, а головне - як допомога школі в комуністичному вихованні майбутніх громадян СРСР.

Отже, аналіз розвитку теоретичних основ $\mathrm{i}$ практики позашкільної освіти показав, що вона має свою історію, зумовлену багатогранністю змісту і форм здійснення. Особливістю позашкільної освіти на початку XX ст. стало розширення iї змісту та урізноманітнення форм організації в позашкільних та інших навчальних закладах. Йшов пошук шляхів розвитку освіти 
дітей поза школою. Велася аналітична робота i приходило усвідомлення необхідності створення умов для позашкілля. Цей час можна розглядати як підготовчий у створенні системи позашкільної освіти. Характерним для 20-30-х рр. ХХ ст. був зв'язок виховання 3 виробництвом, який давав дітям можливість, ознайомившись із декількома професіями, обрати ту чи іншу з них відповідно до власних здібностей i бажань, що сприяло їхній соціалізації в суспільстві. У 1930-1940рр. система позашкільної освіти набувала подальшого розвитку. Мережа позашкільних закладів, зміст позашкільного виховання орієнтувалися на зв'язок із життям, вирішення завдання всебічного розвитку особистості, підготовку до праці та продовження навчання.

\section{ЛІТЕРАТУРА}

1. Балахтар В. Історичний розвиток позашкільної освіти в Україні. Вісник Одеського інституту внутрішніх справ. Одеса, 2007. Вип. 4: Південноукраїнський правничий часопис. С. 279-282.

2. Кірсанов В.В. До визначення предмета рекреації в контексті педагогічних проблем дозвілля. Вісник Книжкової палати. 2004. №9. С. 28-31.

3. Кобзар Б.С. Внеурочная воспитательная работа в школах и группах продленного дня. К. : Радянська школа, 1984. $167 \mathrm{c}$.

4. Молчан О. Дозвілля як важливий фактор соціально-культурної реабілітації молодих інвалідів. Рідна школа. 2002. № 2. С. 29-32.

5. Пенішкевич O.I. Розвиток українського шкільництва на Буковині (XVIII - початок XX ст.) : монографія. Чернівці: Рута, 2002. 520 с.

6. Пенішкевич O.I. Зміст національного виховання учнів у школах Буковини (друга половина XIX початок XX ст.). Науковий вісник Чернівецького університету: зб. наук. праць. Чернівці : Рута, 1999. Випуск 67. С. 3-11.

\section{REFERENCES}

1. Balakhtar V. Istorychnyi rozvytok pozashkilnoi osvity v Ukraini. [Historical development of out-ofschool education in Ukraine.] Visnyk Odeskoho instytutu vnutrishnikh sprav. Odesa, 2007. Vyp. 4: Pivdennoukrainskyi pravnychyi chasopys. S. 279-282.

2. Kirsanov V.V. Do vyznachennia predmeta rekreatsii v konteksti pedahohichnykh problem dozvillia. [Towards determining the subject of recreation in the context of pedagogical problems of leisure.] Visnyk Knyzhkovoi palaty. 2004. № 9. S. 28-31.

3. Kobzar B.S. Vneurochnaya vospitatel 'naya rabota v shkolakh i gruppakh prodlennogo dnya. [Extracurricular educational work at schools and after-school care groups.] K. : Radyanska shkola, 1984. $167 \mathrm{~s}$.

4. Molchan O. Dozvillia yak vazhlyvyi faktor sotsialno-kulturnoi reabilitatsii molodykh invalidiv. [Leisure as an important factor in socio-cultural rehabilitation of young people with disabilities.] Ridna shkola. 2002. № 2. S. 29-32.

5. Penishkevych O.I. Rozvytok ukrainskoho shkilnytstva na Bukovyni (KhVIII - pochatok KhKh st.): [Development of Ukrainian schooling in Bukovyna (18th - early 20th centuries)] Monohrafiia. Chernivtsi: Ruta, 2002. $520 \mathrm{~s}$.

6. Penishkevych O.I. Zmist natsionalnoho vykhovannia uchniv u shkolakh Bukovyny (druha polovyna $\mathrm{KhIKh}$ - pochatok KhKh st.). [The content of national education of students at schools of Bukovina (second half of the XIX - beginning of the XX century).]. Naukovyi visnyk Chernivetskoho universytetu: zb. nauk. prats. Chernivtsi : Ruta, 1999. Vypusk 67. S. 3-11 